\title{
Optimal Hierarchical Decision-Making for Heat Source Selection of District Heating Systems
}

\author{
Fang Fang ${ }^{1,2}$ and Nan Wang ${ }^{1}$ \\ ${ }^{1}$ School of Control and Computer Engineering, North China Electric Power University, Beijing 102206, China \\ ${ }^{2}$ Suzhou Institute of North China Electric Power University, Suzhou 215123, China \\ Correspondence should be addressed to Fang Fang; ffang@ncepu.edu.cn
}

Received 15 August 2014; Revised 23 August 2014; Accepted 23 August 2014; Published 16 November 2014

Academic Editor: Hui Zhang

Copyright (c) 2014 F. Fang and N. Wang. This is an open access article distributed under the Creative Commons Attribution License, which permits unrestricted use, distribution, and reproduction in any medium, provided the original work is properly cited.

\begin{abstract}
With the rapid development of China's urbanization, the proportion between the heating consumption and the energy consumption of the whole society keeps rising in recent years. For a district heating system, the selection of the heat source makes significant impact on the energy efficiency and the pollutant emissions. By integrating the methods of the Analytic Hierarchy Process (AHP) and the Preference Ranking Organization Method for Enrichment Evaluation (PROMETHEE), a multiple-attribute decisionmaking scheme for the heat source selection of district heating systems is proposed in this paper. As a core part of this scheme, a comprehensive benefit index with hierarchical parallel structure is constructed. The economic benefit, environment benefit, and technical benefit can be reflected with a certain percentage in the comprehensive benefit index. To test the efficiency of the proposed scheme, a case study for a large-scale district heating system in Beijing is carried out, where five kinds of heat sources (water source heat pump, ground source heat pump, gas-fired boiler, coal-fired boiler, and oil-fired boiler) are taken into account. The analysis and instructions for the final sorting result are also demonstrated.
\end{abstract}

\section{Introduction}

The district heating is a system for the distributing heat that is generated in a centralized location for residential and commercial heating requirements. Compared with the localized heating system, the district heating system can reach higher efficiency and provide better pollution control. With the rapid development of China's urbanization, the district heating system has become an indispensable infrastructure. Till the end of 2013, the district heating area in China has reached 63.6 billion square meters and this number is six times as many as in 2000 [1]. But the higher energy consumption, the lower equipment efficiency, and the unreasonable load match between the capacity of heating equipment and the users' load at the end of the heating network still restrict the healthy development of the district heating systems.

As we know, there are three essential elements of the district heating systems: the heat sources, the heating pipe networks, and the heat users. Among them, the heat source is not only the heat provider for the whole heating system, but also the direct consumer of the primary energy. And the overall safety, efficiency, and emissions of the heating system have close relationship with heat sources. Furthermore, the operation mechanism, the energy efficiency, and the primary energy consumption are of significant difference for various types of heat sources. All of the above reasons make the selection of heat sources become the top priority in the planning of district heating systems.

In the face of such a typical complex networked system, the advanced real-time control [2] and the online optimization [3] will be instructive for the daily operation of the district heating system, while performance evaluation and the energy-loss analysis can give important guidance for the planning and construction of heat sources. Hu et al. [4] gave comparative analysis of the characteristics and the energy consumption for five kinds of common heat sources. Chen et al. [5] put forward suggestions and measures for improving the efficiency of heat sources by analyzing the consumptions of fuel, electrical power, water, and heat. Zheng [6] discussed several key problems about energy saving 
from heat sources, heating networks, heating stations, and secondary-level heating networks.

Referring to the advanced experience and considering the needs of social and economic development, multisource and complementarity of heat sources have become the developing trend of the configuration for district heating systems [7]. This situation makes the selection of heat sources a multiobjective and multiconstraint decision-making problem, where the technical performance, the social benefit, and environmental benefit should be considered comprehensively [8]. Wang et al. [9] studied the environmental assessment of heat sources in urban area using fuzzy multiobjective optimization method. Zheng et al. [10] introduced AHP in the evaluation of district heating systems and made a comprehensive evaluation based on the total economic cost. Ghafghazi et al. [11] proposed a multicriteria approach, which can take into account the interests of investors, operators, users, and other stakeholders, to evaluate the district heating system options.

All of the above results suggest the following.

(i) The district heating system has complicated network characteristics that determine the existence of strong technical correlation between the heat source and other elements.

(ii) The heat source, located in a special geographical and social environment, also has significant social and economic attribute.

Therefore, before making the decision of heat source selection, the multilevel and multiattribute index system should be established first. And the advanced evaluation and decisionmaking methods may help to obtain the final result, which can satisfy the global demand under most conditions.

Following the previous researches and referring to advanced decision-making methods applied in complicated systems, in this paper, the Analytic Hierarchy Process (AHP) and the Preference Ranking Organization Method for Enrichment Evaluation (PROMETHEE) are integrated to produce an optimal hierarchical decision-making scheme for heat source selection of district heating systems. The AHP is used for the structure analysis of the candidate heat sources and for the determination of the relative weights of evaluation indices; the PROMETHEE is introduced to sort the candidate heat sources and conclude the optimal results. The combination of the AHP and the PROMETHEE can coordinate the qualitative indices and quantitative indices effectively and can make complicated decision-making problems coherent and structured.

The rest of this paper is organized as follows: a scheme of multiple-attribute decision-making is discussed in Section 2; in Section 3, a comprehensive evaluation index including economic benefit, environment benefit, and technical benefit is proposed for the selection of heat sources; a large-scale district heating system in Beijing is taken as an example for a case study based on the proposed hierarchical decision-making scheme in Section 4; finally, the results and discussion of this work are addressed in Section 5.
TABLE 1: Two types of preference functions.

\begin{tabular}{lcc}
\hline Type & Function name & Form of preference function \\
I $\quad \begin{array}{c}\text { Normal preference } \\
\text { function }\end{array}$ & $P_{c}\left(x_{a}, x_{b}\right)= \begin{cases}1, & \text { if } f_{c}\left(x_{a}\right)-f_{c}\left(x_{b}\right)>0, \\
0, & \text { if } f_{c}\left(x_{a}\right)-f_{c}\left(x_{b}\right) \leq 0,\end{cases}$ \\
II $\quad \begin{array}{c}\text { Quasi preference } \\
\text { function }\end{array}$ & $P_{c}\left(x_{a}, x_{b}\right)= \begin{cases}1, & \text { if } f_{c}\left(x_{a}\right)-f_{c}\left(x_{b}\right)>e, \\
0, & \text { if } f_{c}\left(x_{a}\right)-f_{c}\left(x_{b}\right) \leq e\end{cases}$ \\
\hline
\end{tabular}

\section{Multiple-Attribute Evaluation Scheme}

2.1. Determine the Preference of Alternative by the PROMETHEE. By introducing a preference function, the PROMETHEE method can establish a preference relationship for each alternative. According to the calculation of incoming flow and outgoing flow, an incomplete rank for each alternative can be obtained [12].

Assuming there are $k$ plans in a certain alternative set $X=$ $\left\{x_{1}, x_{2}, \ldots, x_{k}\right\}$ and $h$ indices are included in evaluation index set $F=\left\{f_{1}, f_{2}, \ldots, f_{h}\right\}$.

For arbitrary two alternatives $x_{a} \in X$ and $x_{b} \in X$, define the preference structure under the index $f_{c} \in F$ :

$$
\begin{gathered}
\left.a P b\right|_{f_{c}} \quad \text { iff } f_{c}\left(x_{a}\right)>f_{c}\left(x_{b}\right), \\
\left.a I b\right|_{f_{c}} \text { iff } f_{c}\left(x_{a}\right)=f_{c}\left(x_{b}\right),
\end{gathered}
$$

where $\left.a P b\right|_{f_{c}}$ represents that the preference degree of $x_{a}$ is larger than that of $x_{b}$ for decision makers under the index $f_{c}$, $\left.a I b\right|_{f_{c}}$ represents that the preference degrees of $x_{a}$ and $x_{b}$ are equal, and $f_{c}\left(x_{a}\right)$ and $f_{c}\left(x_{b}\right)$ are attribute values of $x_{a}$ and $x_{b}$ under $f_{c}$.

There are two main types of methods to get the attribute value $f_{c}\left(x_{i}\right)$ : quantitative method and qualitative methods. The former works with the practical engineering calculation or experiment results; the latter is mainly based on rating scale method to decide the importance of alternatives for decision-making.

In order to describe the precedence relationships of the alternatives, the preference function $P_{c}\left(x_{a}, x_{b}\right)$ for index $f_{c}$ is defined to transfer these relationships to numerical values located in $[0,1]$. The preference function usually has six common types [11]. According to the need of this paper, two types of preference functions are selected for decisionmaking as shown in Table 1.

In order to give a quantitative description for the preference degree between any two alternatives clearly, the preference coefficient $\pi\left(x_{a}, x_{b}\right)$ is defined as follows:

$$
\pi\left(x_{a}, x_{b}\right)=\frac{\sum_{c=1}^{h} \omega_{c} p_{c}\left(x_{a}, x_{b}\right)}{\sum_{c=1}^{h} \omega_{c}},
$$

where $\omega_{c}$ is the relative weight of $f_{c}$. It can be calculated by AHP, which will be discussed in Section 2.2. 
TABle 2: The judgment matrix $D_{h}$.

\begin{tabular}{lcccc}
\hline & $f_{1}$ & $f_{2}$ & $\cdots$ & $f_{h}$ \\
\hline$f_{1}$ & $d_{11}$ & $d_{12}$ & $\cdots$ & $d_{1 h}$ \\
$f_{2}$ & $d_{21}$ & $d_{22}$ & $\cdots$ & $d_{2 h}$ \\
$\vdots$ & $\vdots$ & $\vdots$ & $\vdots$ & $\vdots$ \\
$f_{h}$ & $d_{h 1}$ & $d_{h 2}$ & $\cdots$ & $d_{h h}$ \\
\hline
\end{tabular}

Furthermore, the outgoing flow $\phi^{+}\left(x_{a}\right)$, incoming flow $\phi^{-}\left(x_{a}\right)$, and net flow $\phi\left(x_{a}\right)$ are defined for any alternative $x_{a}$ as follows:

$$
\begin{gathered}
\phi^{+}\left(x_{a}\right)=\sum_{i=1}^{k} \pi\left(x_{a}, x_{i}\right), \\
\phi^{-}\left(x_{a}\right)=\sum_{i=1}^{k} \pi\left(x_{i}, x_{a}\right), \\
\phi\left(x_{a}\right)=\phi^{+}\left(x_{a}\right)-\phi^{-}\left(x_{a}\right) .
\end{gathered}
$$

Outgoing flow $\phi^{+}\left(x_{a}\right)$ represents the superior degree of alternative $x_{a}$ to other alternatives. The bigger the value of outgoing flow is, the better the alternative $x_{a}$ is. Incoming flow $\phi^{-}\left(x_{a}\right)$ represents the worse degree of alternative $x_{a}$ than other alternatives. The bigger the value of incoming flow is, the worse the alternative $x_{a}$ is. Net flow $\phi\left(x_{a}\right)$ represents the total preference relationships and is used to determine the final ranking result of alternatives.

2.2. Determine the Relative Weight of Evaluation Index by the AHP. The AHP is usually applied in the analysis for decisionmaking of complex system with multiattribute, multifactors, multilevels, and multicandidates [13]. Here we use it to calculate the relative weights of evaluation indices.

In order to simplify the calculation, the relative weights of evaluation indices are divided into two levels: the objective layer and the attribute layer. The objective layer includes the relative weight final values of evaluation indices; the attribute layer includes the relative importance of evaluation indices obtained by experts' scoring.

Here we also take the alternative set $X=\left\{x_{1}, x_{2}, \ldots, x_{k}\right\}$ and evaluation index set $F=\left\{f_{1}, f_{2}, \ldots, f_{h}\right\}$ as examples. The evaluation index set represents the objective layer. The judgment matrix $D_{h}$, established based on $h$ evaluation indices as shown in Table 2, makes up the attribute layer.

In Table $2, d_{p q}$ is the relative importance of index $f_{p} \in F$ comparing with index $f_{q} \in F$, and there is $d_{p q}=1 / d_{q p}$. When $f_{p}=f_{q}, d_{p q}=1$. The rating scale method is often used to get the relative importance according to experts' scoring. Table 3 shows a typical nine-class scale.

The AHP determines the relative weight for each evaluation index by calculating the weight coefficient of the attribute layer to the objective layer. The geometric mean algorithm can be used for deciding the weight with the advantage of judgment matrix.
TABLE 3: The definition table of nine-class scale.

\begin{tabular}{ll}
\hline Rating scale & Definition (comparing index $f_{p}$ with index $f_{q}$ ) \\
\hline 1 & Indices $f_{p}$ and $f_{q}$ are important equally \\
3 & Index $f_{p}$ is slightly more important than $f_{q}$ \\
5 & Index $f_{p}$ is more important than $f_{q}$ \\
7 & Index $f_{p}$ is more important than $f_{q}$ \\
9 & Index $f_{p}$ is absolutely more important than $f_{q}$ \\
$2,4,6,8$ & Middle important value between above scales \\
\hline
\end{tabular}

(1) Calculate the $h$ th root of the product of $h$ elements in pth row of the judgment matrix:

$$
\omega_{p}^{\prime}=\sqrt[h]{\prod_{q=1}^{h} d_{p q} .}
$$

(2) For index $f_{p}$, the relative weight can be calculated by

$$
\omega_{p}=\frac{\omega_{p}^{\prime}}{\sum_{p=1}^{h} \omega_{p}^{\prime}} .
$$

Through building judgment matrix, the relative weight vector of $h$ evaluation indices can be obtained as $\omega=$ $\left\{\omega_{1}, \omega_{2}, \ldots, \omega_{h}\right\}$

\section{Comprehensive Evaluation Index for the Heat Source Selection}

Combined with the actual needs of the current social and economic development in China, a comprehensive evaluation model for the heat source selection of the district heating system is presented in this paper. This model, giving consideration to social, environmental, and technical interests, consists of the following evaluation indices.

(1) Economic evaluation index: it is used to reflect the influence of heat demand from users on the economic benefit of the heating system.

(2) Environment evaluation index: it is used to reflect the impact on the natural and social environments during the construction and operation of the heating system.

(3) Technical evaluation index: it is used to reflect the influence of energy utilization efficiency on the energy saving operation of the heating system.

Assuming that there are $k$ alternatives $X=\left\{x_{1}, x_{2}, \ldots\right.$, $x_{k}$ \} for the selection of heat sources; the life period of the heating equipment is $m$ years, and the number of installed equipment for each alternative is $n$. Accordingly, some variables and symbols are defined in Nomenclature attached at the end of this paper.

3.1. Economic Benefit Index. Economic benefit index includes the initial construction cost and operation cost. In order to give a quantitative description of economic benefit for 
each alternative, the dynamic annual annuity method [14] is used here for converting the initial investment cost and the operation cost to the equivalent annual annuity $r_{c}^{l}\left(x_{j}\right)$ of $l$ th equipment in $j$ th alternative in its life cycle. Consider

$$
\begin{aligned}
r_{c}^{l}\left(x_{j}\right)= & {\left[C_{\text {ini }}^{l}\left(x_{j}\right)-L_{m}^{l}\left(x_{j}\right) \frac{1}{(1+I)^{m}}\right.} \\
& \left.+m C_{\text {ope }}^{l}\left(x_{j}\right) \frac{1}{(1+I)^{m}}\right] \frac{(1+I)^{m}}{(1+I)^{m}-1}, \\
C_{\text {ope }}^{l}\left(x_{j}\right)= & \sum_{l=1}^{n} c_{\text {fuel }}^{l}\left(x_{j}\right)+c_{\text {dep }}^{l}\left(x_{j}\right)+c_{\text {wel }}^{l}\left(x_{j}\right) .
\end{aligned}
$$

The value of economic benefit for $j$ th alternative is

$$
R_{C}\left(x_{j}\right)=\sum_{l=1}^{n} r_{c}^{l}\left(x_{j}\right)=f\left[C_{\text {ini }}^{l}\left(x_{j}\right), L_{m}^{l}\left(x_{j}\right), C_{\text {ope }}^{l}\left(x_{j}\right), I\right] .
$$

Here $R_{c}\left(x_{j}\right)$, reflecting the equivalent annual operation cost of an alternative in the entire operation period, is the function of initial investment, operation, and management cost, the equipment salvage, and the yield rate of the alternative.

The economic benefit index of $j$ th alternative is the normalizing value of economic benefit. Consider

$$
P_{C}\left(x_{j}\right)=\frac{\min \left\{R_{m}\left(x_{j}\right)\right\}}{R_{m}\left(x_{j}\right)} .
$$

3.2. Environment Benefit Index. Due to the burning of fossil fuels, the boiler-type heat sources will produce gaseous, liquid, and solid pollutants inevitably. Moreover, although they do not consume primary energy, the electric power consumption of the heat-pump-type heat sources can also cause the pollutant emission during the energy conversion process. In this paper, the annual emissions of $\mathrm{SO}_{2}, \mathrm{NO}_{x}, \mathrm{CO}$, $\mathrm{CO}_{2}$, and other pollutants are considered in the environment benefit evaluation, and the PROMETHEE is selected to calculate the quantitative result of the environment benefit index.

Referring to Section 2.1, the environment benefit equations of $j$ th alternative can be deduced from (3). Consider

$$
\begin{gathered}
\phi_{E}^{+}\left(x_{j}\right)=\sum_{i=1}^{k} \pi\left(x_{j}, x_{i}\right), \\
\phi_{E}^{-}\left(x_{j}\right)=\sum_{i=1}^{k} \pi\left(x_{i}, x_{j}\right), \\
\phi_{E}\left(x_{j}\right)=\phi_{E}^{+}\left(x_{j}\right)-\phi_{E}^{-}\left(x_{j}\right),
\end{gathered}
$$

where $\pi\left(x_{j}, x_{i}\right)$ is relevant to the preference function and the weight coefficient. According to the characteristics of real data, the type II preference function is selected to describe $\mathrm{NO}_{x}$ and $\mathrm{SO}_{2}$; the type I preference function is used for other pollutants. The weight vector set of five kinds of gas pollutants is denoted as $\omega_{E}=\left\{\omega_{1}, \omega_{2}, \omega_{3}, \omega_{4}, \omega_{5}\right\}$. Referring to Table 2, a five-order judgment matrix $D_{5}$ can be built. The value of every element in $D_{5}$ is rated by decision makers and experts based on Table 3 .

According to the judgment matrix $D_{5}$, the relative weight for each pollutant attribute can be obtained referring to (4) and (5). Furthermore, the economic benefit index of $j$ th alternative can be normalized as

$$
P_{E}\left(x_{j}\right)=\frac{\phi_{E}\left(x_{j}\right)}{\max \left\{\phi_{E}\left(x_{j}\right)\right\}} \text {. }
$$

$\phi_{E}\left(x_{j}\right)<0$ means that the environment benefit of $j$ th alternative has no advantage compared with other alternatives. This alternative should be excluded directly from the alternative set.

3.3. Technical Benefit Index. Technical benefit index contains five aspects: the technical sophistication, the heating quality, safety and suitability, local resource condition, and energy utilization efficiency. Same as the calculation of environment benefit index, the PROMETHEE is adopted. Consider

$$
\begin{gathered}
\phi_{T}^{+}\left(x_{j}\right)=\sum_{i=1}^{k} \pi\left(x_{j}, x_{i}\right), \\
\phi_{T}^{-}\left(x_{j}\right)=\sum_{i=1}^{k} \pi\left(x_{i}, x_{j}\right), \\
\phi_{T}\left(x_{j}\right)=\phi_{T}^{+}\left(x_{j}\right)-\phi_{T}^{-}\left(x_{j}\right) .
\end{gathered}
$$

Since the real values of the five technical attributes are difficult to be measured in practice, the rating scale method, which draws support from expert scoring or questionnaire, is the common choice.

The normalized technical benefit index of $j$ th alternative can be got by

$$
P_{T}\left(x_{j}\right)=\frac{\phi_{T}\left(x_{j}\right)}{\max \left\{\phi_{T}\left(x_{j}\right)\right\}} .
$$

3.4. Comprehensive Benefit Index. Based on the above analysis, a comprehensive benefit index for the heat source selection can be established:

$$
P\left(x_{j}\right)=\alpha_{c} P_{C}\left(x_{j}\right)+\alpha_{e} P_{E}\left(x_{j}\right)+\alpha_{t} P_{T}\left(x_{j}\right),
$$

where $\alpha_{c}+\alpha_{e}+\alpha_{t}=1$ to ensure $P\left(x_{j}\right) \in[0,1]$. The objective of the heat source selection is to find the alternative with maximal $P\left(x_{j}\right)$.

The comprehensive benefit index evaluates the performance of the heat sources from three aspects: economy, environment, and technology. A typical hierarchical parallel structure can be seen between the three aspects and the comprehensive benefit index as Figure 1. 


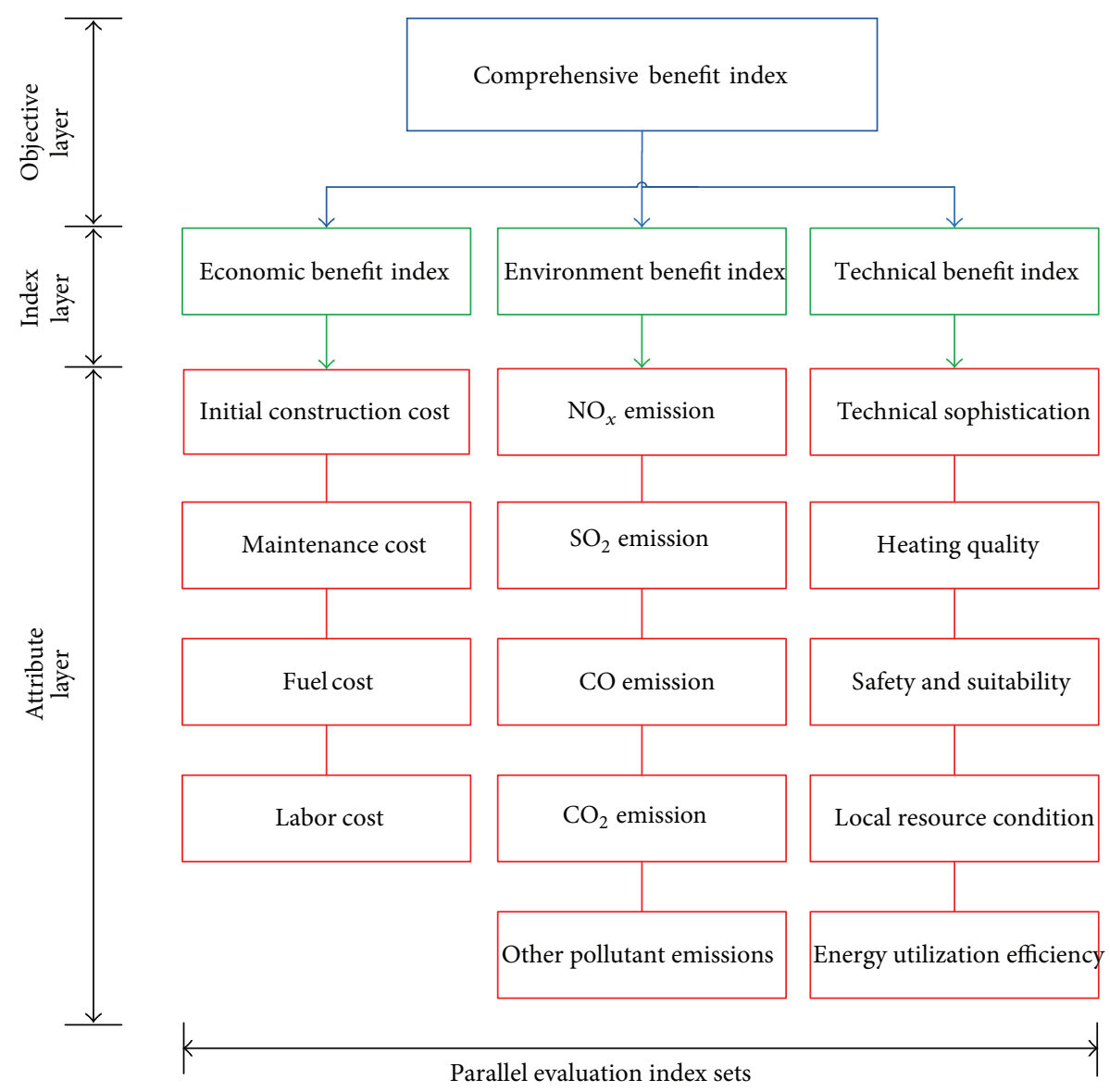

FIGURE 1: The hierarchical parallel structure of the comprehensive benefit index.

\section{Case Study}

A large-scale district heating system for a community with $330000 \mathrm{~m}^{2}$ heat supply area in Beijing is taken as an example for analysis. This heating system mainly undertakes the supply of daily living hot water and heating supply in winter. The heating supply period of Beijing in winter is 129 days, and the lowest indoor average temperature is $24^{\circ} \mathrm{C}$. Referring to the algorithm given in [11], the peak heat load of this community can be estimated as $16 \mathrm{MW}$ and the maximum total heat demand in winter is about $49536 \mathrm{MWh}$.

There are two types, five alternative heat sources for this district heating system. The first type is boiler-type, which includes oil-fired boiler, coal-fired boiler, and gas-fired boiler. The second type is heat-pump-type, which includes ground source heat pump and water source heat pump. The significant differences which exist between the two types are as follows: boiler-type heat sources usually burn fossil fuels, and heat-pump-type heat sources do not consume the fossil fuels during the operation; the rated load and return water temperature difference of boiler-type heat sources are higher than those of heat-pump-type heat sources; in the users side, radiation heat exchangers are commonly used for boiler-type heat sources, and coil pipe exchangers are usually adopted for heat-pump-type heat sources. For case studies, operation parameters of the five heat sources are listed in Table 4 .
4.1. Economic Benefit Evaluation. Initial construction cost and operation cost are two key factors affecting the economic benefit of each alternative directly. The sample data for the calculation of the economic benefit index comes from the completed engineering projects and the related literatures [15-17].

For boiler-type heat sources, construction cost of main body equipment, such as boiler and turbine, accounts for a large percentage of initial investment. For heat-pump-type heat sources, the initial investment mainly concentrates in the hot well, the underground heat exchanger, and so forth. The initial construction cost of each alternative is shown in Table 5.

Annual operation and management cost includes annual fuel cost, annual electric power cost, labor cost, maintenance cost, and annual depreciation cost. For boiler-type heat sources, fuel cost accounts for a large percentage of the annual operation and management cost. Although the heat-pumptype heat sources have no energy consumption during the operation, the huge amount of electric power consumption has to be considered.

For the $16 \mathrm{MW}$ peak heat load, the heat source number of each alternative can be determined according to the rated heating capacity shown in Table 4 . Combining with the system scale, heating period, energy consumption in rated 
TABLE 4: The operation parameters of alternatives.

\begin{tabular}{|c|c|c|c|c|c|}
\hline Items & $\begin{array}{l}\text { Oil-fired } \\
\text { boiler }\end{array}$ & $\begin{array}{c}\text { Gas-fired } \\
\text { boiler }\end{array}$ & $\begin{array}{c}\text { Coal-fired } \\
\text { boiler }\end{array}$ & $\begin{array}{l}\text { Ground source } \\
\text { heat pump }\end{array}$ & $\begin{array}{c}\text { Water source } \\
\text { heat pump }\end{array}$ \\
\hline Rated heat capacity (MW) & 4.2 & 4.2 & 5.6 & 2.8 & 2.8 \\
\hline $\begin{array}{l}\text { Temperature difference between supply } \\
\text { water and return water }\left({ }^{\circ} \mathrm{C}\right)\end{array}$ & 20 & 20 & 20 & 10 & 10 \\
\hline Energy source & Oil/electric power & $\begin{array}{c}\text { Gas/electric } \\
\text { power }\end{array}$ & $\begin{array}{c}\text { Coal/electric } \\
\text { power }\end{array}$ & $\begin{array}{c}\text { Geothermy/electric } \\
\text { power }\end{array}$ & $\begin{array}{c}\text { Water/electric } \\
\text { power }\end{array}$ \\
\hline Fuel consumption $(\mathrm{Kg} / \mathrm{h})$ & 393 & $480\left(\mathrm{~m}^{3} / \mathrm{h}\right)$ & 1120 & - & - \\
\hline Rated power consumption $(\mathrm{Kw})$ & 18.5 & 18.5 & 12.5 & 757 & 660 \\
\hline $\begin{array}{l}\text { Power consumption of accessory } \\
\text { equipment }(\mathrm{Kw})\end{array}$ & 37 & 37 & 65 & 85 & 90 \\
\hline
\end{tabular}

TABLE 5: The initial construction investments of alternatives.

\begin{tabular}{|c|c|c|c|c|c|}
\hline Items & $\begin{array}{l}\text { Oil-fired } \\
\text { boiler }\end{array}$ & $\begin{array}{c}\text { Gas-fired } \\
\text { boiler }\end{array}$ & $\begin{array}{c}\text { Coal-fired } \\
\text { boiler }\end{array}$ & $\begin{array}{l}\text { Ground source } \\
\text { heat pump }\end{array}$ & $\begin{array}{c}\text { Water source } \\
\text { heat pump }\end{array}$ \\
\hline $\begin{array}{l}\text { Construction cost for terminal } \\
\text { equipment }\left(10^{4} \mathrm{RMB}\right)\end{array}$ & 1158.03 & 1158.03 & 1158.03 & 2427.46 & 2427.46 \\
\hline $\begin{array}{l}\text { Construction cost for pipeline } \\
\left(10^{4} \mathrm{RMB}\right)\end{array}$ & 150 & 150 & 150 & 230 & 230 \\
\hline $\begin{array}{l}\text { Construction cost for heat station and } \\
\text { accessory equipment }\left(10^{4} \mathrm{RMB}\right)\end{array}$ & 330 & 310 & 400 & 2618 & 1880 \\
\hline $\begin{array}{l}\text { Total investment cost for initial } \\
\text { construction }\left(10^{4} \mathrm{RMB}\right)\end{array}$ & 1638.03 & 1618.03 & 1708.03 & 5275.46 & 4537.46 \\
\hline
\end{tabular}

condition, and fuel prices, the cost of maximum primary energy consumption and electric power consumption can be got for alternatives. However, referring to the real heating load in winter, heating supply of the heat source must be changed to meet the user's needs and the rated output cannot be held throughout day and night. In order to describe the actual energy consumption reasonably, an equivalent energy consumption coefficient ( $\mu_{h}$ reflects the average load rate of main equipment in a heating period) and equivalent electric power consumption coefficient ( $\mu_{\varepsilon}$ reflects the average power consumption rate in a heating period) are introduced here. The real energy consumption of alternatives can be calculated by multiplying the rated maximum energy consumption and the equivalent energy consumption coefficient. By the same way, the electric power consumption can be got. For the heatpump-type heat sources, there is no consumption of primary energy and the overall energy conversion efficiency is higher; an attenuation coefficient $(\eta=0.75)$ should be considered when calculating the real electric power consumption [18].

A boiler-type $16 \mathrm{MW}$ district heating system usually needs more than 30 employees. Due to the high level of automation, the heat-pump-type system with the same capacity only requires the half number of employees. The wage for one employee is assumed as $24000 \mathrm{RMB}$ per winter and the welfare is $11 \%$ of the wage. The maintenance cost in one running period is accounted as $2.5 \%$ of the total initial investment. The depreciation of equipment is calculated as $5 \%$ of the initial investment. The detailed operation costs of alternatives are displayed in Table 6.

Equivalent annual annuity method is used to evaluate the economic benefit. Accounting the salvage value after service life of one alternative is $10 \%$ of the initial investment, the service life is $m=15$ years and the yield rate is $I=11 \%$ (including the fixed rate $I_{0}=7 \%$ and the risk rate $I_{r}=4 \%$ ). Based on (6), (7), the economic benefits of five alternatives are calculated and shown in Table 7.

The sorting result of economic benefits is as follows:

coal-fired boiler $>$ water source heat pump $>$ gas-fired boiler $>$ ground source heat pump $>$ oil-fired boiler.

Energy consumption and price are the two important factors influencing the economic benefit. The amount of primary energy consumption of coal-fired boiler is the largest in all alternatives. However, the fact of lower coal price in China helps reduce the operation cost in service cycle. Although heat-pump-type systems use new energy resources and avoid the consumption of fossil fuel energy, the much more electric power consumption in operation cycle and the initial investment make their economic benefits lower than traditional boiler-type systems.

The prices of oil, coal, natural gas, and electric power are fluctuating with time and location. So the different decision results may be obtained for different engineering projects. At the same time, the selection of heat-pump-type heat source should also depend on the local natural condition.

4.2. Environment Benefit Evaluation. During the winter heating period, environmental pollution caused by the district heating system depends on the fuel type and consumption. Here, gaseous pollutants, which influence atmospheric environment directly, are selected as indicator for environment benefit evaluation.

The empirical method is usually used for estimating the gaseous pollutions during one heating period. By analyzing 
TABLE 6: The annual operation costs of alternatives.

\begin{tabular}{|c|c|c|c|c|c|}
\hline Items & $\begin{array}{l}\text { Oil-fired } \\
\text { boiler }\end{array}$ & $\begin{array}{c}\text { Gas-fired } \\
\text { boiler }\end{array}$ & $\begin{array}{c}\text { Coal-fired } \\
\text { boiler }\end{array}$ & $\begin{array}{l}\text { Ground source } \\
\text { heat pump }\end{array}$ & $\begin{array}{l}\text { Water source } \\
\text { heat pump }\end{array}$ \\
\hline The number of installed heat sources & 4 & 4 & 5 & 6 & 6 \\
\hline $\begin{array}{l}\text { Primary energy consumption } \\
\left(10^{4} \mathrm{~kg} / \text { year }\right)\end{array}$ & 267.68 & $326.92\left(\mathrm{~m}^{3}\right)$ & 572.13 & - & - \\
\hline Fuel cost $\left(10^{4} \mathrm{RMB} /\right.$ year $)$ & 1338.40 & 745.40 & 514.90 & - & - \\
\hline $\begin{array}{l}\text { Power consumption for main } \\
\text { equipment }\left(10^{4} \mathrm{KWh} / \text { year }\right)\end{array}$ & 16.04 & 16.04 & 8.13 & 788.27 & 643.65 \\
\hline Power cost $\left(10^{4} \mathrm{RMB} /\right.$ year $)$ & 9.62 & 9.62 & 4.88 & 442.96 & 386.19 \\
\hline $\begin{array}{l}\text { Power consumption for accessory } \\
\text { equipment }\left(10^{4} \mathrm{KWh} / \text { year }\right)\end{array}$ & 32.07 & 32.07 & 42.26 & 106.62 & 117.01 \\
\hline $\begin{array}{l}\text { Power cost of accessory equipment } \\
\left(10^{4} \mathrm{RMB} / \text { year }\right)\end{array}$ & 28.86 & 28.86 & 38.034 & 95.96 & 105.31 \\
\hline Wages and welfare $\left(10^{4} \mathrm{RMB} /\right.$ year $)$ & 7.92 & 7.92 & 7.92 & 3.96 & 3.96 \\
\hline Maintenance cost $\left(10^{4} \mathrm{RMB} /\right.$ year $)$ & 40.95 & 40.45 & 42.70 & 68.81 & 59.59 \\
\hline $\begin{array}{l}\text { Depreciation of equipment } \\
\left(10^{4} \mathrm{RMB} / \text { year }\right)\end{array}$ & 81.9 & 80.9 & 85.4 & 137.63 & 119.18 \\
\hline
\end{tabular}

TABLE 7: The economic benefits of alternatives.

\begin{tabular}{lccccc}
\hline Items & $\begin{array}{c}\text { Oil-fired } \\
\text { boiler }\end{array}$ & $\begin{array}{c}\text { Gas-fired } \\
\text { boiler }\end{array}$ & $\begin{array}{c}\text { Coal-fired } \\
\text { boiler }\end{array}$ & $\begin{array}{c}\text { Ground source } \\
\text { heat pump }\end{array}$ & $\begin{array}{c}\text { Water source } \\
\text { heat pump }\end{array}$ \\
\hline$R_{m}\left(10^{4} \mathrm{RMB} /\right.$ year $)$ & 880.34 & 618.42 & 536.06 & 685.83 & 602.86 \\
$P_{c j}$ & 0.609 & 0.887 & 1 & 0.782 & 0.889 \\
\hline
\end{tabular}

and accounting the real data of running process, the pollutant emission coefficients are defined for various fuel combustion processes. Thus, the quantitative relationship between pollutant emission and fuel consumption can be established [19]. In this work, $\mathrm{NO}_{x}, \mathrm{SO}_{2}, \mathrm{CO}, \mathrm{CO}_{2}$, and other gaseous pollutants are taken into account and the detailed emission data is listed in Table 8.

Following the method stated in Section 2.2, the relative weights of gaseous pollutions are calculated to establish the judgment matrix as Table 9.

Based on (11) and (12), the relative weight set of environment benefit is acquired for five alternatives:

$$
\omega_{E}=\{0.267,0.448,0.087,0.178,0.02\} \text {. }
$$

Furthermore, referencing to the PROMETHEE, the type II preference function is adopted for $\mathrm{NO}_{x}$ and $\mathrm{SO}_{2}$, and the type I preference function is used for other gaseous pollutions. According to (2) and (9)-(12), the environment benefits of the five alternatives are calculated as shown in Table 10. Here, the negative value of the environment benefit means that both of the coal-fired boiler and the oil-fired boiler have no advantage in environmental benefit compared to other alternatives.

The sorting result of environment benefits is as follows:

water source heat pump $>$ ground source heat pump $>$ gas-fired boiler $>$ oil-fired boiler $=$ coal-fired boiler.

4.3. Technical Benefit Evaluation. According to Section 3.3, quantitative technical benefits of alternatives are obtained as Table 11.
The relative weights of technical attributes are calculated to establish the judgment matrix as Table 12 .

Referring to the calculation process of environment benefit, the relative weight set of technical benefit for five alternatives is got. Consider

$$
\omega_{T}=\{0.154,0.257,0.188,0.054,0.347\} .
$$

As discussed in Sections 2.1 and 3.3, type I preference function is used here. According to (2), (13)-(14), the values of incoming flow, outgoing flow, and net flow are calculated and listed in Table 13.

The sorting result of technical benefits is as follows:

ground source heat pump $>$ water source heat pump $>$ gas-fired boiler $>$ oil-fired boiler $=$ coal-fired boiler.

4.4. Comprehensive Evaluation. Based on the above analysis and calculation about economic benefit, environment benefit, and technical benefit, the comprehensive benefit of alternatives can be calculated by AHP with (15). Consider

$$
P\left(x_{j}\right)=\{0.277,0.583,0.455,0.797,0.898\},
$$

where the weight factor of each benefit is selected as $\left\{\alpha_{c}, \alpha_{e}, \alpha_{t}\right\}=\{0.455,0.461,0.084\}$. So the final sorting result of five alternatives is as follows:

water source heat pump $>$ ground source heat pump $>$ gas-fired boiler $>$ coal-fired boiler $>$ oil-fired boiler. 
TABLE 8: The annual pollutant emissions of alternatives.

\begin{tabular}{lccccc}
\hline Items & $\begin{array}{c}\text { Oil-fired boiler } \\
\left(\mathrm{g} / \mathrm{m}^{2}\right)\end{array}$ & $\begin{array}{c}\text { Gas-fired boiler } \\
\left(\mathrm{g} / \mathrm{m}^{2}\right)\end{array}$ & $\begin{array}{c}\text { Coal-fired } \\
\text { boiler }\left(\mathrm{g} / \mathrm{m}^{2}\right)\end{array}$ & $\begin{array}{c}\text { Ground source } \\
\text { heat pump }\left(\mathrm{g} / \mathrm{m}^{2}\right)\end{array}$ & $\begin{array}{c}\text { Water source } \\
\text { heat pump }\left(\mathrm{g} / \mathrm{m}^{2}\right)\end{array}$ \\
\hline $\mathrm{NO}_{x}$ & 11.97 & 7.85 & 40.54 & 2.18 & 1.854 \\
$\mathrm{SO}_{2}$ & 13.10 & 7.914 & 12.34 & 3.84 & 3.264 \\
$\mathrm{CO}$ & 0.361 & 0.016 & 1.974 & 0.0236 & 0.0206 \\
$\mathrm{CO}_{2}$ & 4159.38 & 2695.65 & 2810.13 & 570.31 & 484.76 \\
Others & 1.87 & 2.2886 & 5.097 & 0.529 & 0.449 \\
\hline
\end{tabular}

TABLE 9: The judgment matrix for environment evaluation index.

\begin{tabular}{lccccc}
\hline Items & $\mathrm{NO}_{x}$ & $\mathrm{SO}_{2}$ & $\mathrm{CO}$ & $\mathrm{CO}_{2}$ & Others \\
\hline $\mathrm{NO}_{x}$ & 1 & $1 / 3$ & 7 & 2 & 8 \\
$\mathrm{SO}_{2}$ & 3 & 1 & 8 & 3 & 7 \\
$\mathrm{CO}$ & $1 / 7$ & $1 / 8$ & 1 & $1 / 5$ & 4 \\
$\mathrm{CO}_{2}$ & $1 / 2$ & $1 / 3$ & $1 / 4$ & 1 & 6 \\
Others & $1 / 8$ & $1 / 7$ & $1 / 6$ & 1 \\
\hline
\end{tabular}

TABLE 10: The environment benefits of alternatives.

\begin{tabular}{lccccc}
\hline Items & $\begin{array}{c}\text { Oil-fired } \\
\text { boiler }\end{array}$ & $\begin{array}{c}\text { Gas-fired } \\
\text { boiler }\end{array}$ & $\begin{array}{c}\text { Coal-fired } \\
\text { boiler }\end{array}$ & $\begin{array}{c}\text { Ground source } \\
\text { heat pump }\end{array}$ & $\begin{array}{c}\text { Water source } \\
\text { heat pump }\end{array}$ \\
\hline$\phi_{E}{ }^{+}(j)$ & 1.02 & 2.2445 & 0 & 2.689 & 2.3405 \\
$\phi_{E}{ }^{-}(j)$ & 2.8465 & 1.398 & 4 & 0.9625 & 0.087 \\
$\phi_{E}(j)$ & -1.8265 & 0.8465 & -4 & 1.7265 & 2.2535 \\
$P_{E}(j)$ & - & 0.3756 & - & 0.7661 & 1 \\
\hline
\end{tabular}

TABLE 11: Attribute table of technical benefit* .

\begin{tabular}{lccccc}
\hline Items & $\begin{array}{c}\text { Oil-fired } \\
\text { boiler }\end{array}$ & $\begin{array}{c}\text { Gas-fired } \\
\text { boiler }\end{array}$ & $\begin{array}{c}\text { Coal-fired } \\
\text { boiler }\end{array}$ & $\begin{array}{c}\text { Ground source } \\
\text { heat pump }\end{array}$ & $\begin{array}{c}\text { Water source } \\
\text { heat pump }\end{array}$ \\
\hline Technical sophistication & 4 & 4 & 5 & 3 & 3 \\
Heat quality & 4 & 4 & 5 & 3 & 3 \\
Safety and suitability & 2 & 3 & 4 & 5 & 5 \\
Local source condition & 2 & 3 & 2 & 5 & 5 \\
Energy utilizing efficiency & 3 & 3 & & 5 & 5 \\
\hline
\end{tabular}

${ }^{*}$ Five-class scale is used here, and the larger is better.

TABLE 12: The judgment matrix for technical attributes.

\begin{tabular}{|c|c|c|c|c|c|}
\hline Items & $\begin{array}{c}\text { Technical } \\
\text { sophistication }\end{array}$ & Heat quality & $\begin{array}{l}\text { Safety and } \\
\text { suitability }\end{array}$ & $\begin{array}{l}\text { Local source } \\
\text { condition }\end{array}$ & $\begin{array}{c}\text { Energy utilizing } \\
\text { efficiency }\end{array}$ \\
\hline Technical sophistication & 1 & $1 / 2$ & $1 / 2$ & 5 & $1 / 2$ \\
\hline Heat quality & 2 & 1 & 3 & 4 & $1 / 3$ \\
\hline Safety and suitability & 2 & $1 / 3$ & 1 & 5 & $1 / 2$ \\
\hline Local source condition & $1 / 5$ & $1 / 4$ & $1 / 5$ & 1 & $1 / 3$ \\
\hline Energy utilizing efficiency & 2 & 3 & 2 & 3 & 1 \\
\hline
\end{tabular}

TABLE 13: The technical benefits of alternatives.

\begin{tabular}{lccccc}
\hline Items & $\begin{array}{c}\text { Oil-fired } \\
\text { boiler }\end{array}$ & $\begin{array}{c}\text { Gas-fired } \\
\text { boiler }\end{array}$ & $\begin{array}{c}\text { Coal-fired } \\
\text { boiler }\end{array}$ & $\begin{array}{c}\text { Ground source } \\
\text { heat pump }\end{array}$ & $\begin{array}{c}\text { Water source } \\
\text { heat pump }\end{array}$ \\
\hline$\phi_{T}{ }^{+}(j)$ & 1.169 & 1.653 & 1.928 & 2.114 & 1.767 \\
$\phi_{T}{ }^{-}(j)$ & 2.019 & 1.589 & 2.114 & 1.281 & 1.628 \\
$\phi_{T}(j)$ & -0.85 & 0.064 & -0.186 & 0.833 & 0.139 \\
$P_{T}(j)$ & - & 0.076 & - & 1 & 0.166 \\
\hline
\end{tabular}




\section{Results and Discussion}

Considering three benefits (the economic benefit, the environment benefit, and the technical benefit), the water source heat pump is selected by the proposed hierarchical decisionmaking scheme as the best heat source of the district heating system for a community in Beijing. Compared to the ground source heat pump that can only be applied at geothermal location, the water source heat pump has a variety of energy sources (such as the groundwater, the surface water, the industrial waste water, or the living waste water) and therefore is more likely to be accepted.

In boiler-type alternatives, gas-fired boiler has the best comprehensive benefit. In the geothermal and water scarcity area, gas-fired boiler will be the preference selection for the district heating system. Although the coal-fired boiler has the best economic benefit, it still cannot be selected as an ideal solution for its worse environment benefit.

This work shows that the integration of the PROMETHEE and the AHP makes the qualitative and quantitative attributions easy to be treated together in the decision-making process. The case study further indicates that, in broader areas of industrial and civil engineering, the proposed hierarchical decision-making scheme has promising developing trend.

\section{Nomenclature}

$P_{j}: \quad$ Comprehensive benefit index for $j$ th alternative

$\alpha_{C}$ : Weight for economic benefit index

$\alpha_{E}$ : Weight for environment benefit index

$\alpha_{T}$ : Weight for technical benefit index

$I$ : $\quad$ Yield rate

$P_{C}\left(x_{j}\right)$ : Normalized economic benefit index for $j$ th alternative

$P_{E}\left(x_{j}\right)$ : Normalized environment benefit index for $j$ th alternative

$P_{T}\left(x_{j}\right): \quad$ Normalized technical benefit index for $j$ th alternative

$R c\left(x_{j}\right): \quad$ Economic benefit value for $j$ th alternative

$r_{c}^{l}\left(x_{j}\right): \quad$ Equivalent annual annuity of $l$ th equipment in $j$ th alternative

$C_{\text {ini }}^{l}\left(x_{j}\right)$ : Initial construction cost of $l$ th equipment in $j$ th alternative

$C_{\text {ope }}^{l}\left(x_{j}\right)$ : Operation and management cost of $l$ th equipment in $j$ th alternative

$C_{\text {fuel }}^{l}\left(x_{j}\right)$ : Fuel cost of $l$ th equipment in $j$ th alternative

$C_{\text {dep }}^{l}\left(x_{j}\right)$ : Maintenance cost of $l$ th equipment in $j$ th alternative

$C_{\text {wel }}^{l}\left(x_{j}\right)$ : Labor cost of $l$ th equipment in $j$ th alternative

$L_{m}^{l}\left(x_{j}\right): \quad$ Residual value at the end of life cycle of $l$ th equipment for $j$ th alternative

$\phi_{E}\left(x_{j}\right): \quad$ Environment benefit value for $j$ th alternative

$\phi_{E}^{+}\left(x_{j}\right)$ : Outgoing flow of environment benefit evaluation for $j$ th alternative
$\phi_{E}^{-}\left(x_{j}\right)$ : Incoming flow of environment benefit evaluation for $j$ th alternative

$\phi_{T}\left(x_{j}\right)$ : Technical benefit value for $j$ th alternative

$\phi_{T}^{+}\left(x_{j}\right)$ : Outgoing flow of technical benefit evaluation for $j$ th alternative

$\phi_{T}^{-}\left(x_{j}\right)$ : Outgoing flow of environment benefit evaluation for $j$ th alternative.

\section{Conflict of Interests}

The authors declare that there is no conflict of interests regarding the publication of this paper.

\section{Acknowledgments}

This work was supported in part by the National Natural Science Foundation of China (NSFC) under Grant 61203107, in part by the Beijing Education Committee Cooperation Building Foundation Project, in part by the Fundamental Research Funds for the Central Universities under Grant 13ZD07, and in part by the Applied Basic Research Programs of Suzhou under Grant SYG201352.

\section{References}

[1] National Bureau of Statistics of China, National Economy and Society Developed Statistical Bulletin 2013, Chinese Statistics Press, Beijing, China, 2014.

[2] H. Zhang and J. Wang, "Combined feedback-feedforward tracking control for networked control systems with probabilistic delays," Journal of the Franklin Institute: Engineering and Applied Mathematics, vol. 351, no. 6, pp. 3477-3489, 2014.

[3] H. Zhang, Y. Shi, and J. Wang, "On energy-to-peak filtering for nonuniformly sampled nonlinear systems: a markovian jump system approach," IEEE Transactions on Fuzzy Systems, vol. 22, no. 1, pp. 212-222, 2014.

[4] J. S. Hu, H. Meng, and Z. J. Li, "Analysis on feature and energy consumption of various heating sources," Applied Energy Technology, no. 148, pp. 46-49, 2010.

[5] Y. H. Chen, S. J. Liu, and X. X. Lv, "Analysis on energy consumption of heat source for central heating system," Building Energy Efficiency, vol. 35, no. 2, pp. 52-55, 2007.

[6] Y. L. Zheng, "Discussion about energy saving scheme of urban centralized heat supplying system," Cogeneration Power Technology, no. 86, pp. 4-7, 2005.

[7] H. Shu, L. Duanmu, C. Zhang, and Y. Zhu, "Study on the decision-making of district cooling and heating systems by means of value engineering," Renewable Energy, vol. 35, no. 9, pp. 1929-1939, 2010.

[8] B. Wei, S.-L. Wang, and L. Li, "Fuzzy comprehensive evaluation of district heating systems," Energy Policy, vol. 38, no. 10, pp. 5947-5955, 2010.

[9] W. Wang, Z. H. Zhang, and X. W. Sheng, "Evaluation of influence of the urban heat source on the environment," Low Temperature Architecture Technology, vol. 100, pp. 81-82, 2004.

[10] Z. H. Zheng, L. Fu, H. F. Di et al., "Comprehensive evaluation of urban heating types with analytic hierarchy process," Heating Ventilating \& Air Conditioning, vol. 39, no. 8, pp. 96-98, 2009. 
[11] S. Ghafghazi, T. Sowlati, S. Sokhansanj, and S. Melin, "A multicriteria approach to evaluate district heating system options," Applied Energy, vol. 87, no. 4, pp. 1134-1140, 2010.

[12] W. de Keyser and P. Peeters, "A note on the use of PROMETHEE multicriteria methods," European Journal of Operational Research, vol. 89, no. 3, pp. 457-461, 1996.

[13] K. M. A.-S. Al-Harbi, "Application of the AHP in project management," International Journal of Project Management, vol. 19, no. 1, pp. 19-27, 2000.

[14] H. Cheng and Q. Chen, Engineering Project Management, China Building Industry Press, Beijing, China, 2009.

[15] S. H. Li and H. Kang, Practical Manual for Central Heating, China Electric Power Press, Beijing, China, 2006.

[16] Y. Fu, B. Lin, and X. Zhang, "Technical and economic analysis of deep well water source heat pump system," Journal of Tongji University, vol. 34, no. 10, pp. 1384-1388, 2006.

[17] W. Xu, Design Manual of Ground Source Heat Pump, China Building Industry Press, Beijing, China, 2009.

[18] Y. Jiang, "Heating schemes analysis for medium and large cities in the north china," Heating Ventilating \& Air Conditioning, vol. 30, no. 4, pp. 30-32, 2000.

[19] Environmental Protection Department of China, The Standards of Air Pollutions Emission for Power Plant, China Environment Science Press, Beijing, China, 2011. 


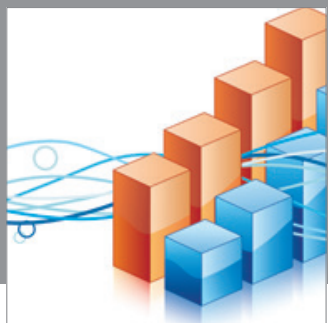

Advances in

Operations Research

mansans

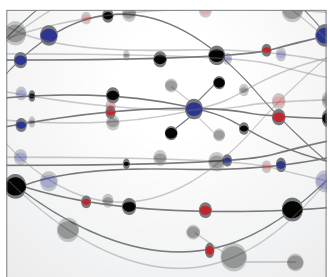

The Scientific World Journal
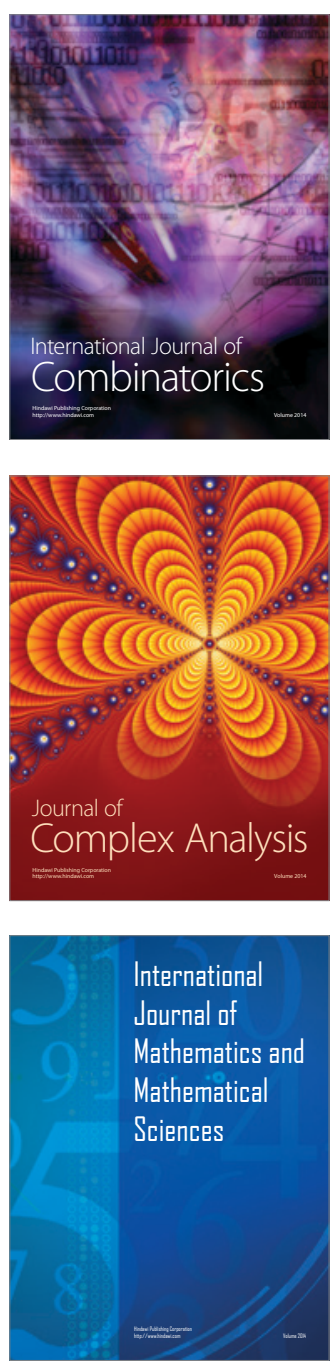
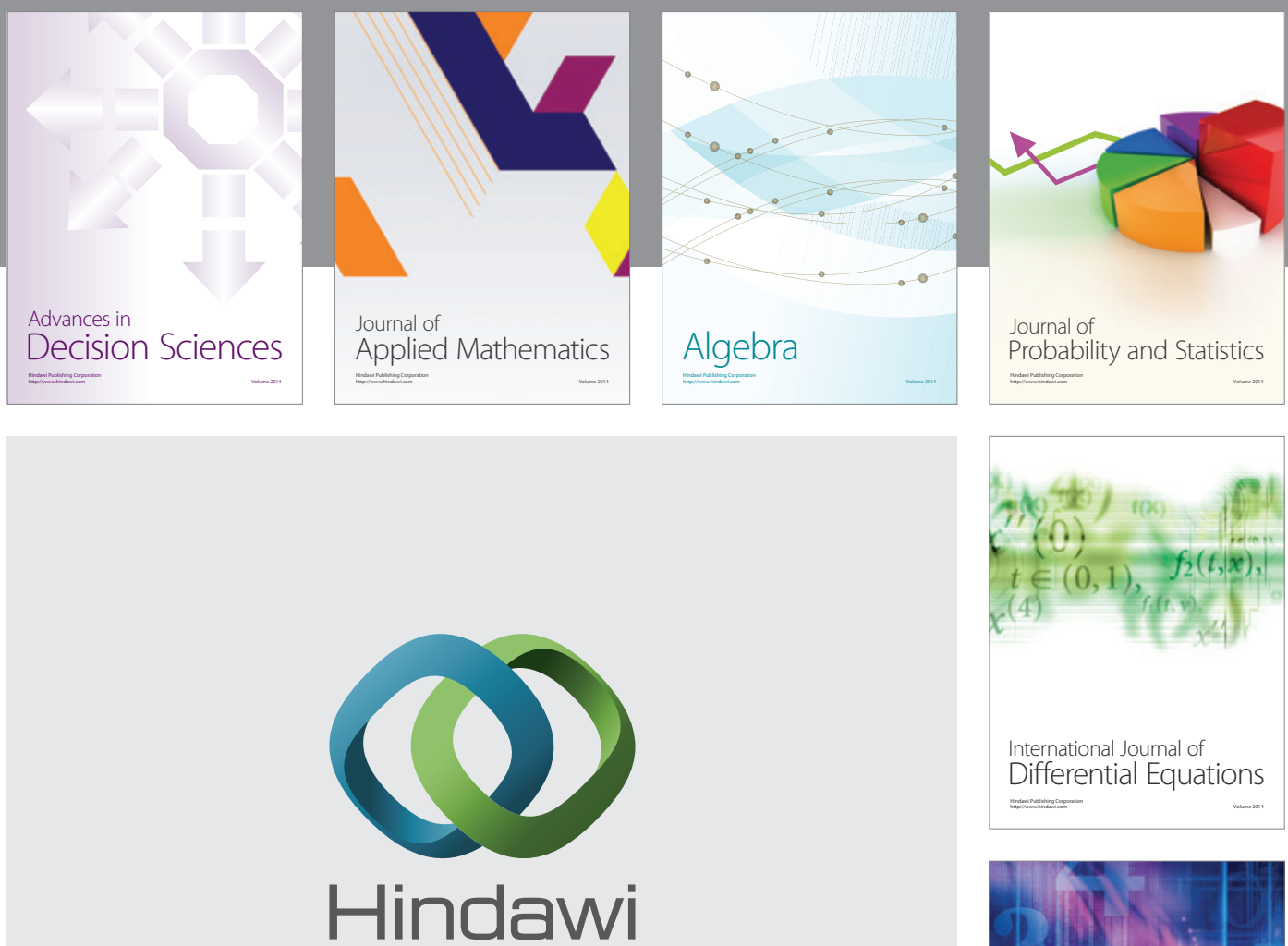

Submit your manuscripts at http://www.hindawi.com
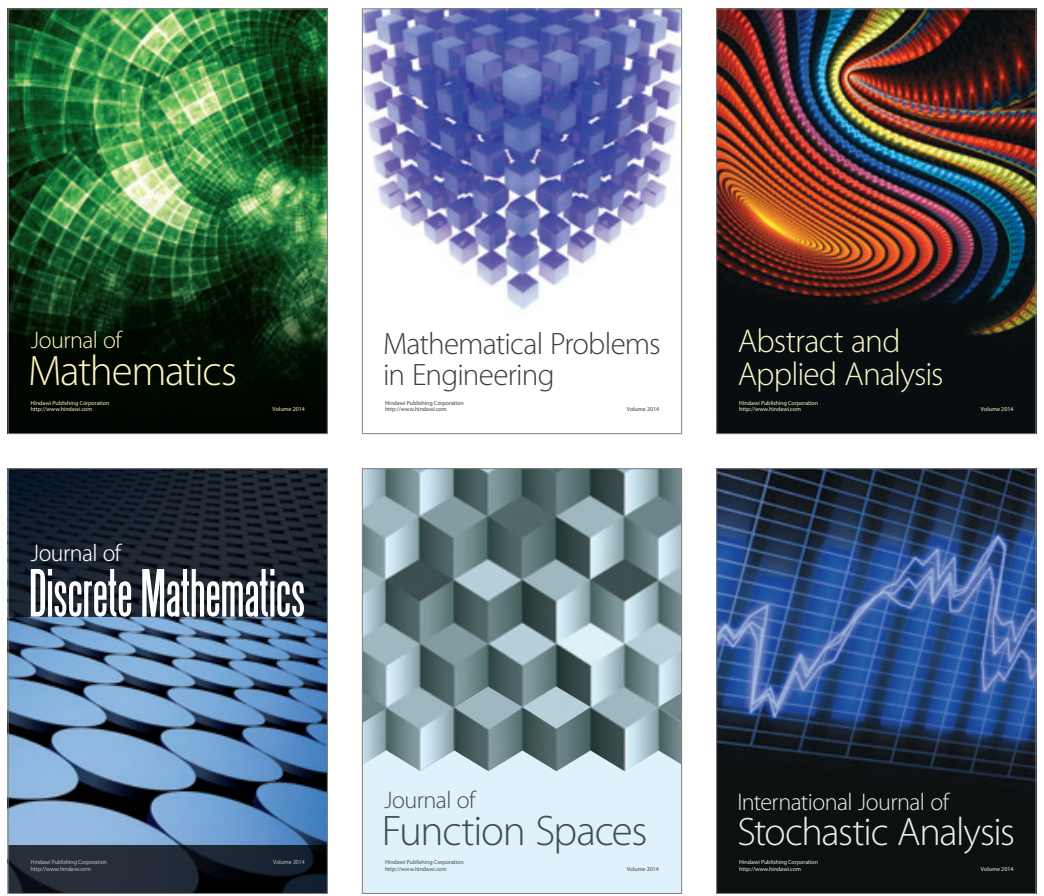

Journal of

Function Spaces

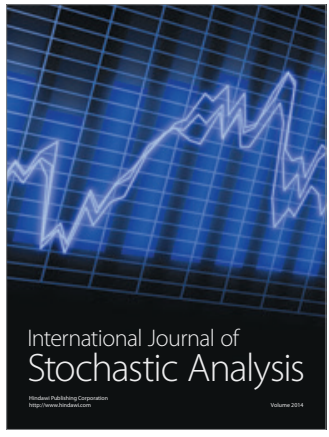

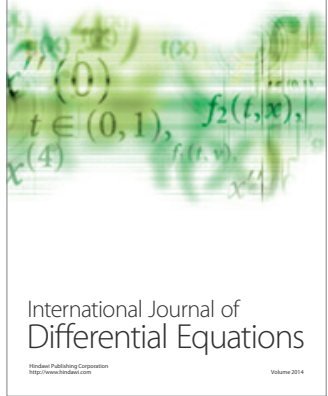
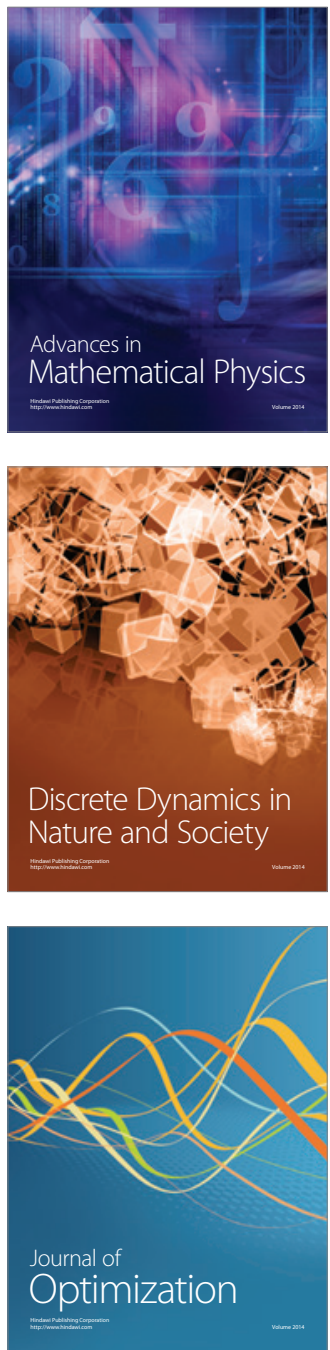